\title{
Research on the Localization of Management of FDI Japanese Companies in Mid China Risks and Obstacles
}

\author{
Katsuhiko Nakajima and Luo Fan
}

\begin{abstract}
Due to appreciation of CNY (Chinese Yuan), labor shortage, rising payroll, increased land and operating costs, Chinese economy in coastal areas faced a lagging development, however, investments to the areas surround Yangtze River are increasing. In Hubei province, which is the core province of this regional area, there are 364 Japanese companies. Most of them are auto mobile related companies. In this area, the Investments from Japan are increasing.

October 2014, we did survey 59 Japanese companies in Hubei province and surroundings in Mid China. In this research we analyze the companies' operation and latest managerial staffs' localization situation based on the company structures, employee number, and operating years. Also we discuss the risk of delay for localization of management in Mid China Foreign Direct Invests of Japanese (FDIJ) compare with United States, and China entire.
\end{abstract}

Index Terms - FDI, management localization, mid china, risk management.

\section{INTRODUCTION}

Since the Chinese Economic Opening up to the Outside World and Reform in 1979, a large amount of Japanese enterprises entered Chinese market. They used cheaper labor cost to build the export production plant originally, but in recent years, it is difficult for Japanese companies to survive if only rely on shrinking Japanese domestic market. Therefore, they started to consider China as a market instead of production place gradually, and promote the investment to China. However, in Japan, the shortage of manpower for overseas activity is a serious problem due to the declining birth rate and the expanding overseas activities. In addition, the payroll of a dispatched Japanese employ abroad is extremely higher than local employees. These caused the limitations to overseas company operation. To solve these problems, localization of managerial staff is unavoidable. Also especially in China, due to the change of working environment caused by the rapidly raised salary and the labor rights awareness, the management of labor is getting more important than before.

Manuscript received January 19, 2017; Revised February 27, 2017.

Katsuhiko Nakajima is with Wuhan University of Technology Management School, Wuhan, Hubei Province, People's Republic of China (e-mail: kcband@outlook.jp).
Japan External Trade Organization [1] introduced the current operation situation and the change of labor environment of Japanese companies in the North and South America, Asia, Oceania and China. Also Organization for Small \& Medium Enterprises and Regional Innovation JAPAN [2] did an investigation of Japanese companies in China regarding the labor management risks and solutions. Han Minheng [3] did surveys of 8 Japanese manufacturing companies to understand the development of local labor capability and localization of managerial staff, and then conclude the reason of failure of localization is the training to local employees was not enough to be able to replace the Japanese staff. Tian Yuan [4] did the case study of both of Japanese HQ and FDI company in China at the point of the management right transferring to overseas. Guanglai [5] concluded that Japanese companies were aware of the importance of localization of management, but it is not proceeded well, and those causes were not because of local companies but Japan head offices. Wang [6] pointed out that those Japanese companies did not use labor CSR measurements in China so that there could be the risk in business.

Previous researches typically used China coastal areas' information to discuss whole situation of China. There were no comparisons with other places in the world. This research focuses on the Mid China areas and compares them with whole China and other places in the world, and then carries out discussions.

\section{Localization OF FDIJ MANAGEMENT IN MID ChINA}

Based on our survey of 59 FDIJs in Mid Chine, we analyze quantitative and qualitative analysis.

\section{A. Multiple Regression Analysis and Correlation Coefficient Analysis}

The ratio of NS (National Staff: Chinese) manager in the total manager is analyzed by nine variables showed in the Table I. In here FDIJ Company Form dummies are 1: for wholly owned by Japanese, 2: for Japanese owned more than $50 \% \mathrm{~J} / \mathrm{V}, 3$ : for Japanese owned less and equal $50 \% \mathrm{~J} / \mathrm{V}$. We use Excel Multiple Regression Analysis.

The Table I showed the results of multi regression analysis for the localization of manager, which shows the ratio of NS manager in the total manager, is related with Company Form(+), Manager Ratio in the total employee(-), and NS manager ratio in the total employee $(+)$.

Also using Excel Correlation Analysis (carrel), we analyze 
the localization of management with FDIJ variables in Table II. In this analysis, addition to Multiple Regression Analysis results, for the small employee FDIJ $(<100)$, employee number affects the localization of management, and for large employee FDIJ $(500<)$, operation years and type of corporation affect the localization.

TABLE I: MULTIPLE REGRESSION ANALYSIS FOR THE LOCALIZATION OF MANAGEMENT IN FDIJ

\begin{tabular}{|c|c|c|c|c|c|c|c|c|}
\hline \multicolumn{2}{|c|}{ Regression statistics } & & & & & & & \\
\hline Multiple correlation $\mathrm{R}$ & 0.845256306 & & & & & & & \\
\hline Multiple determination R2 & 0.714458222 & & & & & & & \\
\hline Correction R2 & 0.662011773 & & & & & & & \\
\hline Standard error & 0.187666518 & & & & & & & \\
\hline The number of observations & 59 & & & & & & & \\
\hline \multicolumn{9}{|l|}{ Analysis of variance table } \\
\hline & Degree of freedom & Fluctuation & Dispersion & Observed varial & Significance $F$ & & & \\
\hline Regression & 9 & 4.317942479 & 0.47977139 & 13.62262339 & $1.27609 \mathrm{E}-10$ & & & \\
\hline Residual error & 49 & 1.72571738 & 0.03521872 & & & & & \\
\hline \multirow[t]{2}{*}{ Total } & 58 & 6.043659859 & & & & & & \\
\hline & Coefficient & Standard Error & $\mathrm{t}$ & $P$-Value & Lower Limit 95\% & Upper Limit 95\% & ower Limit 95.0\% & Upper Limit 95.0\% \\
\hline Intercept & 0.559288167 & 0.237821653 & 2.35171255 & 0.022751462 & 0.081367662 & 1.037208673 & 0.081367662 & 1.037208673 \\
\hline Company form dummy & 0.090755997 & 0.034778616 & 2.60953443 & 0.011991044 & 0.020865751 & 0.160646243 & 0.020865751 & 0.160646243 \\
\hline Total workforce & $-6.08576 \mathrm{E}-05$ & 0.000549261 & -0.110799 & 0.912228352 & -0.001164639 & 0.001042924 & -0.001164639 & 0.001042924 \\
\hline Regular employment & $9.58895 \mathrm{E}-05$ & 0.000562043 & 0.17060888 & 0.865233849 & -0.001033578 & 0.001225357 & -0.001033578 & 0.001225357 \\
\hline Regular employment Ratio & -0.022621086 & 0.24776794 & -0.0912995 & 0.927626847 & -0.520529403 & 0.47528723 & -0.520529403 & 0.47528723 \\
\hline Manager Total & -0.011055139 & 0.003635972 & -3.0404909 & 0.003785417 & -0.018361898 & -0.00374838 & -0.018361898 & -0.00374838 \\
\hline Manager Ratio & -2.361791262 & 0.329748682 & -7.1623979 & $3.71841 \mathrm{E}-09$ & -3.024446048 & -1.699136476 & -3.024446048 & -1.699136476 \\
\hline NS Manager Total & 0.01537565 & 0.005029535 & 3.05707191 & 0.003614229 & 0.005268421 & 0.025482878 & 0.005268421 & 0.025482878 \\
\hline NS Manager Ratio & 3.291860357 & 0.385187973 & 8.54611408 & $2.82749 \mathrm{E}-11$ & 2.517796145 & 4.065924568 & 2.517796145 & 4.065924568 \\
\hline Established number of years & -0.003616616 & 0.004973883 & -0.7271213 & 0.4706115 & -0.013612008 & 0.006378775 & -0.013612008 & 0.006378775 \\
\hline
\end{tabular}

TABLE II: CORRELATION COEFFICIENT ( $※ 1$ ) BETWEEN $\ulcorner$ NS RATIO IN MANAGER 」AND OTHER VARIABLES

\begin{tabular}{|c|c|c|c|c|c|c|c|}
\hline & & & & & & & \\
\hline & & & Type of FDIJ & & Total E & Employee Nun & er trelation \\
\hline & 全データ & Holly $O$ wn & & $\mathrm{J} / \mathrm{V}$ & & $100 \sim 500$ & \\
\hline & & Holly UWII & \begin{tabular}{|l|l} 
More than $50 \%$ Own $(※ 2)$ & I
\end{tabular} & Less than $50 \%$ Own $(※ 3)$ & $<100$ & $100 \sim 500$ & $500<$ \\
\hline Total Employee Number & 0.1288 & 0.1670 & $\begin{array}{r}-0.0715 \\
\end{array}$ & -0.0518 & 0.5205 & 0.0246 & 0.2590 \\
\hline Ordinary Employee Number & 0.1126 & 0.1546 & -0.0952 & $\begin{array}{ll}-0.0788 \\
\end{array}$ & 0.4981 & -0.1165 & 0.2293 \\
\hline Ordinary Employee Ratio \% & -0.1287 & -0.0854 & -0.2222 & -0.2597 & -0.0558 & 0.2432 & 0.0814 \\
\hline Number of Manager & 0.1689 & 0.3795 & 0.3560 & -0.0846 & 0.3590 & 0.3795 & -0.1184 \\
\hline Number of NS Manager & 0.2489 & 0.4202 & 0.5526 & 0.0083 & 0.4535 & 0.5156 & 0.0744 \\
\hline Ratio of Manager \% & -0.1931 & 0.0163 & -0.2705 & -0.3194 & -0.0914 & 0.4096 & -0.7701 \\
\hline Ratio of NS Manager \% & 0.4664 & 0.5404 & 0.5962 & 0.0339 & 0.5131 & 0.6003 & -0.5470 \\
\hline Established number of years & 0.1138 & 0.0441 & 0.1876 & 0.0671 & 0.1830 & 0.1205 & 0.4659 \\
\hline Type of Corporation Dummy Number & 0.1746 & - & - & - & 0.2056 & -0.0131 & -0.6703 \\
\hline ※1 Correlation Coefficient are, $0.0 \sim$ & o Correlatio & $\pm 0.2 \sim \pm 0$ & Neal Correlation、 $\pm 0.4 \sim$ & :Recognize Co & & & \\
\hline $\begin{array}{l}※ 2 \text { JV more than } 50 \% \text { own } \\
※ 3 \text { JV less than } 50 \% \text { own }\end{array}$ & Joint Venture/J: & Japanese own $\mathrm{m}$ & more than $50 \%$ & & & & \\
\hline
\end{tabular}

TABLE III: CORRELATION COEFFICIENT $(※ 1$ ) BETWEEN $\ulcorner$ NS RATIO IN MANAGER 」AND OTHER VARIABLE

\begin{tabular}{|c|c|c|c|c|c|c|c|c|}
\hline \multirow{3}{*}{ FDIJ Form } & \multirow{3}{*}{\multicolumn{2}{|c|}{ Holly Own Company }} & & & & & Unit: People & \\
\hline & & & \multicolumn{4}{|c|}{ Joint Venture Company } & \multirow{2}{*}{\multicolumn{2}{|c|}{ Total }} \\
\hline & & & \multicolumn{2}{|c|}{$50 \%<$} & \multicolumn{2}{|c|}{$<50 \%$} & & \\
\hline Number of Corporation & 37 & & 11 & & 11 & & \multicolumn{2}{|c|}{59} \\
\hline (1) Total Employee (Average of Employee) & 12,501 & 338 & 1,726 & 157 & 5,654 & 514 & 19,881 & 337 \\
\hline (2) Number of Ordinary Employee (\% of (1) & 11,678 & $93.4 \%$ & 1,648 & $95.5 \%$ & 5,022 & $88.8 \%$ & 18,348 & $92.3 \%$ \\
\hline (3) Number of Manager ( $\%$ of (1) & 614 & $4.9 \%$ & 112 & $6.5 \%$ & 524 & $9.3 \%$ & 1,250 & $6.3 \%$ \\
\hline (4) Number of NS Manager ( $\%$ of (3)) & 481 & $78.3 \%$ & 72 & $64.3 \%$ & 345 & $65.8 \%$ & 898 & $71.8 \%$ \\
\hline
\end{tabular}

\section{B. Categorized Analysis of the Localization of Management in Mid China FDIJ}

In the above, we used the Multiple Regression Analysis and Correlation Coefficient Analysis methods. However, we cannot get the clear vision of the management localization in FDIJ in Mid China. Therefore we categorize the data step by step.

1) Localization of management by the Corporate Type in Mid China FDIJ

Table III indicates the localization of management by the corporate type in Mid China FDIJ. Japanese share is higher, manager ratio is lower and localization of manager is higher. This means that FDIJ100\% is reducing number of Japanese employees to push the localization. This figure showed the share of corporation is related with the localization of management.

2) Localization of Management by the Corporation Size in Mid China FDIJ

The average number of employee of FDIJ Mid China is 337 in the 59 companies. In these, manager in total employee is $6.3 \%$, the localization of management is $71.8 \%$. In Table IV showed, large companies $(500<)$ and small companies $(<100)$ are not proceeded well the management localization.

3) Localization of Management by the Operation Year in Mid China FDIJ

Table V showed the relation between FDIJ operation year and the localization of management. The result is clearly determined that FDIJ are localizing manager year by year. The longer operation years FDIJ have higher localization of management.

The above statistical analysis ( Multiple Regression and Correlation Coefficient analysis) and Categorized analysis showed the following results for the localization of management in Mid China FDIJ.

It is affected by:

1) FDIJ corporate Form which means Joint Venture or Wholly owned,

2) Corporate employee size, and

3) Corporate operating years. 


\section{LABOR ISSUES IN FDIJ}

In the Section II, we analyzed the relation between the localization of management and the corporate variables. In this section we try to find out what are the actual problems to precede the localization.

\section{1) Labor Issues of the Mid China FDIJ}

Table VI is the result of the labor issue research of Mid China 59 FDIJ companies based on the multiple choice of answer.

Their major problems are wages, retention of employee, adoption difficulties, higher costs of Japanese, and the localization of management.

2) The measure to the localization of management

To the above labor issue, the localization of management is the major solution for FDIJ. Table VII showed the measure how to precede the localization by areas. FDIJs in Mid china are more focusing the training NS comparing to USA, Asia, and China entire. However the decision or authority transition is still low.

3) The obstacles of the localization for FDIJ

The obstacles are shown at Table VIII in below. The obstacles can be summarized two categories. The first category is caused by Japan side; the second category is caused by local side. The Table VIII shows local side issues are more than that of Japan side. For the FDIJ in Mid China, over $20 \%$ of them answered as problem in questionnaire are as the following topics. (The percentage in ( ) is the answered rate in questionnaires in Mid China).

TABLE IV: LoCALIZATION OF MANAGEMENT By THE CORPoRATE Size In Mid CHINA FDIJ

\begin{tabular}{|c|c|c|c|c|c|c|c|c|}
\hline & & & & & \multicolumn{4}{|c|}{ Unit: People } \\
\hline Number of Employee & \multicolumn{2}{|c|}{$<100$} & \multicolumn{2}{|c|}{$100 \sim 500$} & \multicolumn{2}{|c|}{$500<$} & \multicolumn{2}{|c|}{ Total } \\
\hline Number of Corporation & \multicolumn{2}{|c|}{30} & \multicolumn{2}{|c|}{22} & \multicolumn{2}{|c|}{7} & \multicolumn{2}{|c|}{59} \\
\hline (1) Total Employee (Average of Employee) & 1,117 & 37 & 4,744 & 216 & 14,020 & 2,003 & 19,881 & 337 \\
\hline (2) Number of Ordinary Employee (\% of (1)) & 1,078 & $96.5 \%$ & 3,868 & $81.5 \%$ & 13,402 & $95.6 \%$ & 18,348 & $92.3 \%$ \\
\hline (3) Number of Manager (\% of (1)) & 155 & $13.9 \%$ & 417 & $8.8 \%$ & 678 & $4.8 \%$ & 1,250 & $6.3 \%$ \\
\hline (4) Number of NS Manager ( $\%$ of (3)) & 107 & $69.0 \%$ & 342 & $82.0 \%$ & 449 & $66.2 \%$ & 898 & $71.8 \%$ \\
\hline
\end{tabular}

TABLE V: Localization OF MANAGEMENT By THE OPERATION YEAR IN Mid CHINA FDIJ

\begin{tabular}{|c|c|c|c|c|c|c|c|c|}
\hline \multirow{3}{*}{\begin{tabular}{|l} 
Established Year \\
Number of Corporation \\
\end{tabular}} & & & & & & & People & \\
\hline & \multicolumn{2}{|c|}{ Y1990 1Y1999 } & \multicolumn{2}{|c|}{ Y2000 Y2009 } & \multicolumn{2}{|c|}{ Y2010 } & \multicolumn{2}{|c|}{ Total } \\
\hline & \multicolumn{2}{|c|}{6} & \multicolumn{2}{|c|}{22} & \multicolumn{2}{|c|}{31} & \multicolumn{2}{|c|}{59} \\
\hline (1) Total Employee (Average of Employee) & 3,471 & 579 & 8,084 & 367 & 8,326 & 269 & 19,881 & 337 \\
\hline (2) Number of Ordinary Employee (\% of (1) & 3,199 & $92.2 \%$ & 7,410 & $91.7 \%$ & 7,739 & $92.9 \%$ & 18,348 & $92.3 \%$ \\
\hline (3) Number of Manager (\% of (1)) & 208 & $6.0 \%$ & $354^{\circ}$ & $4.4 \%$ & 688 & $8.3 \%$ & $1,250^{\circ}$ & $6.3 \%$ \\
\hline (4) Number of NS Manager ( $\%$ of (3) & 171 & $82.2 \%$ & 269 & $76.0 \%$ & 458 & $66.6 \%$ & 898 & $71.8 \%$ \\
\hline
\end{tabular}

\begin{tabular}{|c|c|c|c|c|c|c|c|}
\hline $\begin{array}{l}\text { Wage increases } \\
\text { of employees }\end{array}$ & \begin{tabular}{|l|} 
Adoption \\
difficultyame of \\
human resources \\
(general staff clerk)
\end{tabular} & \begin{tabular}{|l|} 
Adoption difficulty \\
human resources \\
(middle \\
management)
\end{tabular} & $\begin{array}{l}\text { Adoption } \\
\text { difficulty of } \\
\text { human resources } \\
\text { (general worker) }\end{array}$ & \begin{tabular}{|l} 
Adoption \\
difficulty of \\
human \\
resources \\
(technician) \\
\end{tabular} & $\begin{array}{l}\text { Retention rate } \\
\text { of employees }\end{array}$ & $\begin{array}{l}\text { The quality of } \\
\text { employee }\end{array}$ & \\
\hline 52 & 19 & 23 & 14 & 15 & 26 & 39 & \\
\hline $21.7 \%$ & $7.9 \%$ & $9.6 \%$ & $5.8 \%$ & $6.3 \%$ & $10.8 \%$ & $16.3 \%$ & \\
\hline \begin{tabular}{|l} 
Cost of \\
Japanese \\
temporary \\
transfer officers \\
(expatriates)
\end{tabular} & $\begin{array}{l}\text { Visa restrictions on } \\
\text { Japanese temporary } \\
\text { transfer officers } \\
\text { (expatriates) }\end{array}$ & \begin{tabular}{|l|} 
Regulations for the \\
dismissal and \\
personnel \\
reduction
\end{tabular} & $\begin{array}{l}\text { localization } \\
\text { difficulty for } \\
\text { management \& } \\
\text { site manager }\end{array}$ & $\begin{array}{l}\text { Employment } \\
\text { regulation of } \\
\text { foreign } \\
\text { workers }\end{array}$ & Other issues & $\begin{array}{l}\text { No particular } \\
\text { problem }\end{array}$ & Total \\
\hline 15 & 5 & 14 & 16 & 0 & 1 & 1 & 240 \\
\hline $6.3 \%$ & $2.1 \%$ & $5.8 \%$ & $6.7 \%$ & $0.0 \%$ & $0.4 \%$ & $0.4 \%$ & $100.0 \%$ \\
\hline
\end{tabular}

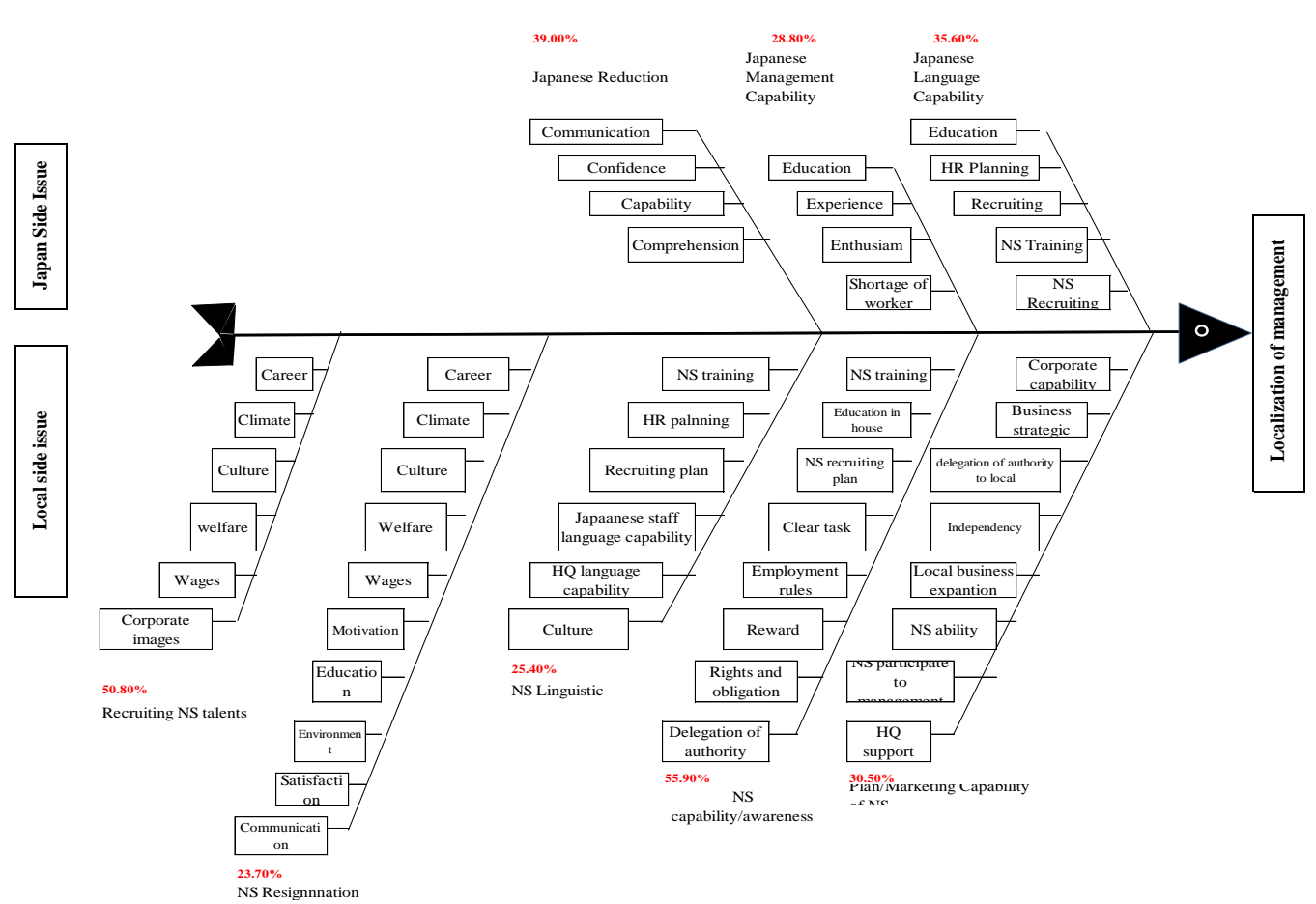

Fig. 1. Major obstacles and key words of FDIJ's localization of management. 
TABLE VII: The MeAsures to LoCALIZATION OF MANAGEMENT By AREA

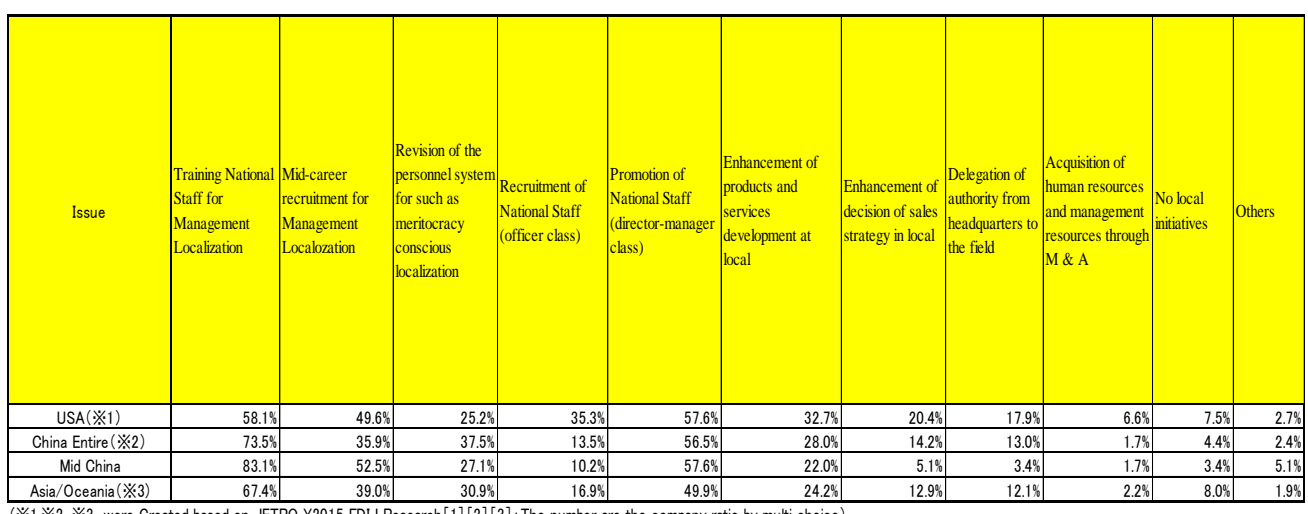

TABLE VIII: OBSTACLES TO THE LOCALIZATION BY AREA

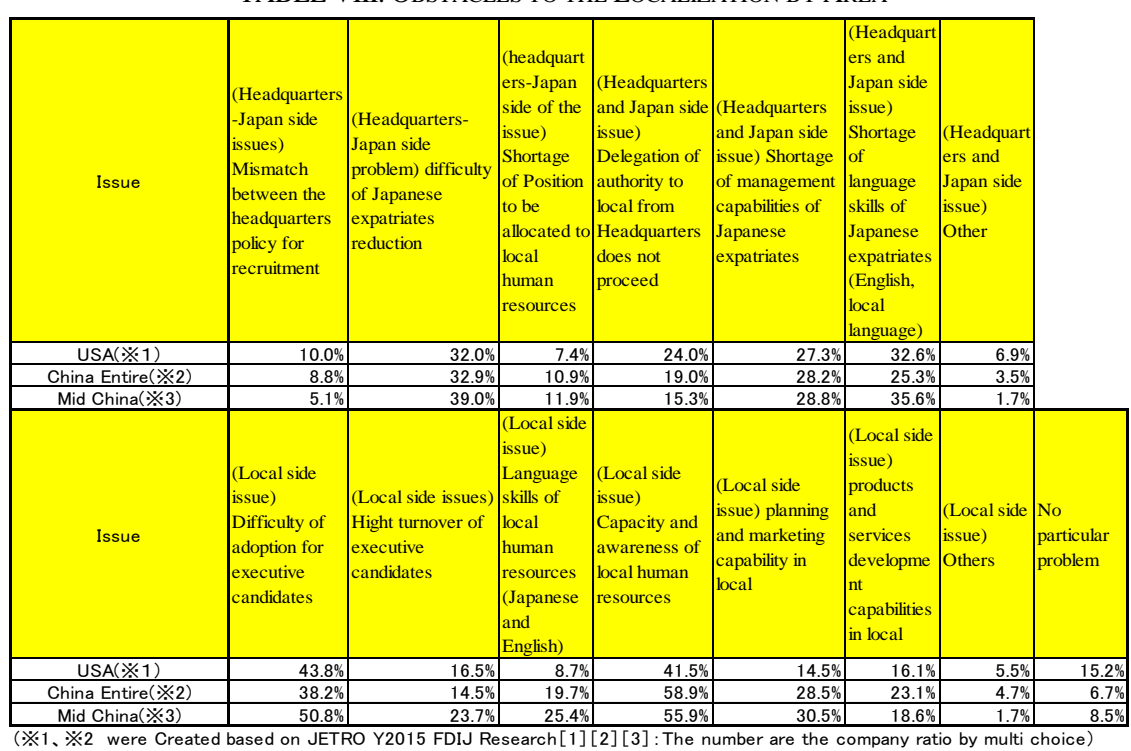

$<$ Head office and Japan side reasons>

1) Difficulties to reduce dispatched Japanese workers $(39.0 \%)$

2) Dispatched Japanese workers have language difficulty $(35.6 \%)$

3) Dispatched Japanese workers have poor management capability $(28.8 \%)$

<Local Issues>

1) NS talents do not have enough motivation and their capability is not enough $(55.9 \%)$.

2) Difficulties to recruit NS talents as backup managerial staffs $(50.8 \%)$.

3) Incapability to do local planning and implementation of market events $(30.5 \%)$.

4) NS linguistic competence is lower (25.4\%).

5) Turnover of NS is Higher (23.7\%)

\section{THE RISK CONTOUR OF EMPLOYEE MANAGEMENT FOR FDIJ IN MID CHINA}

In Table VIII, comparing three area's localization obstacles, the Mid China's rates of local side obstacles are higher than other area. Mid china have more risks of the adoption of executive candidate, high turnover, language skill, and capability more than USA or China entire.

Fig. 1 shows impacts factors (Key factor) to the major obstacles in Table VIII.
To summarize them, the followings are our suggestion how to manage the managerial localization for FDIJ.

1) Considering NS not only worker but also customer:

NS themselves have opinion and spread it to market about the company products. Therefore FDIJ need to improve the treatment to NS, such as proper wages, welfare, work environment, and also need to educate them FDIJ' products confidence.

2) Good communication with NS.

Communication is key factor. To improve communicate with NS, "employee satisfaction survey", "MBO management", "opinion box or mail", and "Labor union" are the efficient tool.

3) Education and training to NS

The other important things are education and training. FDIJ should have clear corporate mission, vison and strategy to share with NS by telling them the future story for their success. Also make it clear carrier step for promotion.

4) Business success

Without the profit, FDIJ cannot give NS the sufficient service. FDIL should have the profit.

On the other hand, the localization of operation also includes relatively higher risk. Recently the large Japanese companies received huge damage by the subsidiary manager's illegality in China. First case was EMORI Shoji who had 109 years history in chemicals, chemical dyes and electronic devices operation. A Chinese manager breached 
the law led to huge losses to company recently. They failed down to excessive debt of 23.4 million yen due to their Chinese subsidiary manager's fictitious sales to his relatives company. At the end of April, they applied Civil Rehabilitation Law. Their Chinese HQ was located Shanghai and office in Wuhan.

Another case is LIXIL, who represents Japanese interior-exterior Company. Due to their subsidiary (Joyou AG, Fujian, local office in Wuhan) manager's book external debt falsification of sales amount and profit, they recorded 66 million losses in April 2016.

Those Chinese operators' illegal events bring huge obstacles to Japanese company's localization of their operation. Therefore, in the process of the localization of their operation, FDIJ need to set up the system and organization which can avoid these illegalities, such as double check system, dispersion of power or authority, periodical audit, periodical position change etc.

\section{CONCLUSION}

Regarding the localization of management of FDIJ Mid China, through Multiple Regression Analysis, Correlation Coefficient Analysis, and Categorized Analysis, we result that it is related with Corporate Form (wholly owned, Joint Venture), corporate size by Employee number, and Operating years.

From this research, the localization of management in Mid China has more difficulty compare with USA or China entire. However the needs for the localization of management are already understood well by FDIJ. Also between FDIJ's Head quarter and FDIJ, there is not much discrepancy of the awareness of necessity for localization. However the causes of delay for them are mainly exist at the Local side. Then we summarize the key factors for localization,

We also point out the risk of localization using examples, and proposed the proper management control. We hope this research can contribute FDI corporation's management and FDI in Mid China is continually expanding.

\section{REFERENCES}

[1] Japan External Trade Organization, "2015 January Investigation of Current Japanese Companies Situation in Asia and Oceania (China)," pp. 1-62, 2014.

[2] Organization for Small \& Medium Enterprises and Regional Innovation, JAPAN, "Investigation of Personnel Risks and Solution of Japanese Companies in China," pp. 1-37, March 2012.

[3] M. Han, "a Study on the Development and training of Middle Management in Japanese subsidiaries in China," Industry Operation 2010, pp. 71-100, Dec. 2010.

[4] Y. Tian, "Research of cultivation of talents serve in Japanese Companies in China," Oberlin University PhD Essay, pp. 1-26, 2009

[5] L. Guang, "Study of current Japanese Company situation in China," 2008 Nihon University Comprehensive Information Research Summary, no. 9, pp. 130-150, 2008.

[6] X. Wang, "Japanese Labor CSR in China," Hitotsubashi University International and Public Policy College Public Economics Project, pp. 1-37, August 2009.

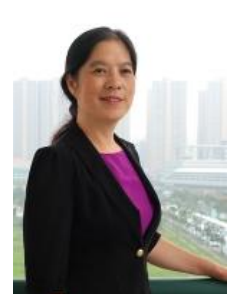

Luo Fan is a professor of School of Management Wuhan University of Technology Director, Research Center of Early Warning Management Ph.D. of Engineering, Wuhan University of Technology Visiting Scholar of University of Minnesota, USA, Member of Public Safety Standards Committee of China Society of Emergency Management, Member of Emergency Management Committee of Chinese Society of Optimization, Overall Planning and Economical Mathematics Council, Member of China Association of Human Resource Development Teaching and Practice Council Member and Director of Risk Management Committee of Hubei Human Resource Association

Her research Fields are human resource development and management, risk early warning management, organizational behavior and organization development, and strategy plan.

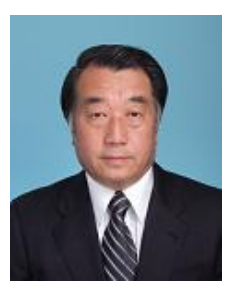

Katsuhiko Nakajima is a manager of Tokyo Metropolitan Small and Medium Enterprise Support Center (Tokyo Japan), and also PhD student of Wuhan University of Technology School of Management (Wuhan, China). He is an experienced dedicated international business person with 21 years oversea residence in USA and China as the manager of Idemitsu Kosan Co., Ltd. (Tokyo Japan) and the business consultation director of Japan External Trade Organization (Tokyo Japan). Graduate Kyushu University Master Degree of Engineering (Fukuoka Japan) and California State University MBA (California USA). His research area is a risk management for Japanese corporation to support Japanese small and medium enterprise business development and continuation. 